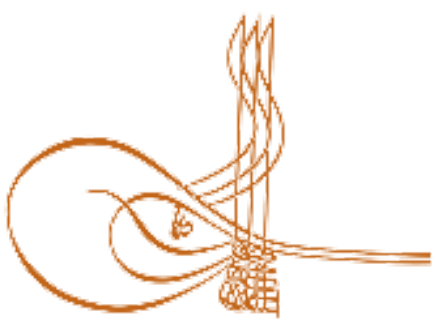

www.turkishstudies.net/language
Turkish Studies - Language and Literature

eISSN: $2667-5641$

Research Article / Araştırma Makalesi

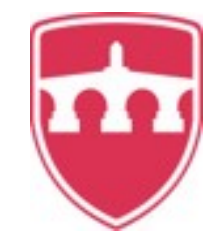

INTERNATIONAL

BALKAN

UNIVERSITY

Sponsored by IBU

\title{
Mehmed Emin Tokadî Hakkında Oluşturulan Memorat Örnekleri
}

Memorate Samples Created About Mehmed Emin Tokadi

\author{
N. Gamze Ilıcak
}

\begin{abstract}
There are many nerrative types like legend, mythe and memorate at literature for Saints, who are described as friends of Allah, are considered to have a high religious authority. The saints whom people love, fear of their anger and take refuge in their intercession are thought to be helping people in need independent of time and place. It is believed that even though the bodies of these people who have eternal life are soil and disappear, their spiritual power continues to exist. The existence of these people is remembered and even their memories are constantly updated with narratives such as legend, legend and memorat created by people. Saints are very important person for people. Mehmed Emin Tokadi, one of the three precious saints of Istanbul, is one of these names. In March-June 2019, a field survey was conducted with a directed interview method. Sixty narratives have been identified and twenty-two of them are the memorates that constitute the subject of the study. This research is based on the kinds of memorates that Özkul Çobanoğlu created in his book Memorates in Turkish Folk Culture. Fifteen of the twenty-two memorates are included in the Çobanoğlu's memorate classification named "Types of Communication Through Dreaming and event that is believed to have occurred". In this study, an examination was made based on this classification. It is extremely important to identify and record the memorates that occur as a result of people's personal experiences. The evaluation of these memorates is also necessary to shed light on social memory.
\end{abstract}

Structured Abstract: Desperate against nature and destiny, man felt the need to seek refuge in spiritual power to overcome the difficulties he had experienced since the primitive ages. Man needs to trust a divine power. For this reason, it is seen that it is expected to benefit from religiously important people called saints and sheikhs.

\footnotetext{
* Dr. Öğr. Üyesi, İstanbul Gelişim Üniversitesi, İktisadi İdari ve Sosyal Bilimler Fakültesi, Türk Dili ve Edebiyatı Bölümü, Türk Halk Edebiyatı

Assist. Prof. Dr, Istanbul Gelisim University, Faculty of Economics, Administrative and Social Sciences, Turkish Language and Literature, Turkish Folk Literature

ORCID 0000-0002-1193-5384

ngilicak@gelisim.edu.tr
}

Cite as/ Atıf: Ilıcak, N. G. (2020). Mehmed Emin Tokadî hakkında oluşturulan memorat örnekleri, Turkish Studies -

Language, 15(1), 207-221. https://dx.doi.org/10.29228/TurkishStudies.39834

Received/Geliş: 20 November/Kasım 2019

Checked by plagiarism software

Accepted/Kabul: 24 March/Mart 2020

Published/Yayın: 30 March/Mart 2020

Copyright (C INTAC LTD, Turkey CC BY-NC 4.0 
Saints, who are described as friends of Allah, are considered to have a high religious authority. People are both afraid of their wrath and punishments and have an eternal respect for them. These people who masters of the spiritual realm are thought to have the ability to be seen in different places at the same time. They heal patients, feeds many people with little food, and even act independently of time and space, helping people throughout their lives and after death. People hope that these people will remedy their hopeless problems.

Mehmed Emin Tokadî is considered as one of the three great saints of Istanbul. Mehmed Emin Tokadi, born in Tokat in 1664, passed away in Istanbul in 1745. This person, who has been trying to serve religion all his life, has entered many sect and received education from many sects. He was able to obtain permission from different sects. This is a testament to his open-mindedness and forward-thinking. Different sects gave him different perspectives and contributed to his personal development.

There are many legends and memorates for saints in public memory. Many legends and memoratas have been created for Mehmed Emin Tokadî and even still continue to be created. This stuation is effected by the prayer which have content "the person who come to Emin Tokadi's grave and read al-fatiha for his soul will protected from hell's fire". In this study, the memorates about Mehmed Emin Tokadî were emphasized.

Memorat is the moments and events that the person believes to have been realized and which is made of extraordinaryness. It is believed that these supernatural moments and events, which are the product of personal experiences, are experienced in reality. Memorates are on the one hand uncanny and frightening. On the other hand, they are magical realities that not everyone can live. It is also difficult to tell and share the memorates with confidence. In addition, because of the it's extraordinary nature its hard to convince someone else with memorates.

In these experiences, the collective consciousness and the cultural codes are quite effective. People are afraid that if they share this moments, they will never have such an experience again. They don't want to tell the memorates. Due to such reasons, there is not much work on the type of memorate.

For this research, a field study was conducted in March-June 2019 using "directed interview" method. Twenty-two of the sixty narratives identified in the field are of the type of memorate. This research is based on the kinds of memorates that Özkul Çobanoğlu created in his book Memorates in Turkish Folk Culture. Fifteen of the twenty-two memorates are included in the Çobanoğlu's memorate classification named "Types of communication through dreaming and event that is believed to have occurred". In this study, an examination was made based on this classification. Memorate texts about Mehmed Emin Tokadî are included in the research text.

Memorates usually occur between sleep and wakefulness or during a dream. The fact that the dream is both a real and supernatural reality, that the soul is free by breaking the chains of the body during the dream, and that the dream is related to the self and nothingness makes the dream special. Although people think that dreams are related to daily life, they also believe that dreams are telling something about the past and the future and dreams are whispering. People are trying to understand whether the choices they make or the events they are going through are good or not. They also think that the divine beings communicate with them during the dream.

This research shows that almost all of the participants think that memorates are related to real life, and that they believe that the reality of the memorates is validated with events they lived. The participants claimed that they had communicated with Mehmed Emin Tokadî during the dream. The participants think that Mehmed Emin Tokadî honored them especially by inviting them to visit and accepting them. Mehmed Emin Tokadî sometimes gave these people some good news for the future and sometimes showed various miracles. Thanks to these, the participants were assured of the 
authenticity of their relations. The participants do not hesitate or doubt that they have communicated with Mehmed Emin Tokadî. According to participants Mehmed Emin Tokadî took part in the dreams of the participants with a divine voice, sometimes with a beam of light, and sometimes with his body form and contacted them in different ways.

Thanks to examples of the type of memorate reflecting today, we can see that Mehmed Emin Tokadî how vivid and dynamic in social memory. When we look at the age range of the participants, it is understood that participants have a wide knowledge about Mehmed Emin Tokadî from young to old. The participants stated that they had information about Mehmed Emin Tokadî through oral communication, documentaries, books and internet. This situation points to the source of current information about Mehmed Emin Tokadî.

The production and transmission of memorates helps Mehmed Emin Tokadî's personality to be carried from past to present. The fact that memorates are still being created shows that the spiritual power of Mehmed Emin Tokadi still continues to be believed. Even centuries after the end of his life, Mehmed Emin Tokadi is a very lively and dynamic religious and cultural actor thanks to these narratives. Increasing the number of such studies is important for understanding what social memory contains.

Keywords: Turkish Folk Literature, Mehmed Emin Tokadî, Saint, Narrative, Dreams, Memorate.

Öz: Allah'ın sevgili kulları olan veliler; dini açıdan mertebesi yüksek kimseler olarak tanımlanmaktadır. Velilere yönelik edebiyatta sayısız menkıbe, efsane, memorat türünde anlatı karşımıza çıkmaktadır. İnsanların sevdikleri, öfkelerinden korktukları aynı zamanda şefaatine sığındıkları veliler, zamandan ve mekândan bağımsız, ihtiyacı olanlara ve darda kalanlara yardım eden kişiler olarak düşünülmektedir. İnanışa göre ebedi yaşama sahip bu zatların, bedenleri toprak olup yok olsa da manevi güçleri varlığını devam ettirmektedir. İnsanlar tarafindan oluşturulan menkıbe, efsane, memorat gibi anlatılarla bu uhrevi kişilerin; mevcudiyetleri hatırlanmakta hatta hatıraları sürekli olarak güncellenmektedir. Veliler, insanlar için dini açıdan kıymetli kişilerdir. İstanbul'un üç kıymetli velisi arasında sayılan Mehmed Emin Tokadî de bu isimlerden biri olarak karşımıza çıkmaktadır. Mart-Haziran 2019 tarihlerinde yönlendirilmiş mülakat yöntemiyle sahada derleme çalışması gerçekleştirilmiştir. Derleme yöntemiyle altmış anlatı tespit edilmiş ve bunlardan yirmi ikisi çalışmanın da konusunu oluşturan memoratlardır. Araştırmada Özkul Çobanoğlu'nun "Türk Halk Kültüründe Memoratlar" adlı kitabında meydana getirdiği memorat çeşitlerinden hareket edilmiştir. Kayda geçirilen yirmi iki memorattan on beşi Çobanoğlu'nun tasnifinde yer alan "Rüya Görme Yoluyla Kurulan İletişim Biçimleri ve Yaşandığına İnanılan Olaylar" sınıflandırmasına girmektedir. Bu tasnif doğrultusunda on beş memorat üzerinden inceleme yapılmıştır. İnsanların şahsi tecrübeleri sonucunda meydana gelen memoratların saptaması, kayda geçirilmesi son derece önemlidir. Toplumsal hafızaya 1 şık tutması açısından bu memoratların değerlendirilmesi ayrıca gereklilik teşkil etmektedir.

Anahtar Kelimeler: Türk Halk Edebiyatı, Mehmed Emin Tokadî, Veli, Anlatı, Rüya, Memorat. 


\section{Giriş}

Şehirleri şehir yapan o şehrin yapılarıdır, yaşanmışlıklarıdır, tarihi eserleridir. O şehre yönelik yazılan şiirler, bestelenen şarkılar, hakkında anlatılan efsaneler, uğruna yakılan türküler, çekilen filmler ve de en önemlisi o şehrin manevi ruhunu oluşturan veliler, şehirlerin zenginlik kaynağıdır. İlahi âlemin bendeleri aynı zamanda efendileri olan bu zatlar, şehirlerin manevi kandilleri ve koruyucuları olarak bilinmektedir. İstanbul da bu açıdan şanslı kentlerden biridir. Yedi tepesinin neredeyse her ilçesinde, her nahiyesinde önemli bir zatın makamı yer almakta ve "Evliyalar Şehri" olarak anılmaktadır.

Yaratılışı gereği insan, aciz ve fakirdir. Başına gelen olaylar, tabiat karşısındaki dermansızlığı insana; biçareliğini derinden hissettirmektedir. Bu yüzden insan, kendinden güçlü manevi bir varlığa ihtiyaç duymaktadır. İnsanlar, Cenâb-1 Hakk'a yakınlık mertebesi kazanmış olduğuna inandıkları, Allah'ın seçkin kulları diye nitelendirdikleri velilere; bu gibi sebeplerle ihtiyaç hissetmekte ve bağl1lı göstermektedir. Bu önemli zatlardan biri de İstanbul'un üç büyük velisi arasında sayılan Mehmed Emin Tokadî’dir. "Kabrine gelip Fatiha okuyanın, cehennem ateşinde yanmaması" duasıyla tanınan Mehmed Emin Tokadi Hazretleri, ayrıca sadece davet ettiklerini makamına kabul ettiği, bu yüzden de onun davetini almayanın oraya gidemeyeceğine inanılan bir zattır.

Zeyrek Yokuşu'nda ebedi istirahatgahında yatmakta olan bu şahsı, her gün yüzlerce kişi ziyaret etmekte ve kişiler onun hayır duasına nail olmaya çalışmakta ve davetine icabet ettiklerini düşünmektedir. Mehmed Emin Tokadî hakkında anlatılagelen pek çok menkıbe, efsane, hikâye bulunmaktadır. $\mathrm{Bu}$ anlatı türlerinden biri de memoratlardır. Realitede gerçekliği tam olarak ispat edilemeyen, ama insanlar tarafından yaşandığına inanılan fevkalâdelikleri barındıran anlar ve olaylardan meydana gelen memoratlar; kişinin şahsi deneyimine dayanmaktadır. Bunların bir kısmı rüya görme yoluyla gerçekleşmektedir.

Sembollerle örülü bir dünya, farklı bir âlem olan rüyalar; bilinmezliklere gebedir. Vücudun sabit kalırken ruhun gezindiği bu metafiziksel yolculuk; yüzyıllardan beri araştırılmakta ama ortaya tam, kesin bir cevap konulamamaktadır. Bu araştırmada da derleme yoluyla tespit edilen memorat çeşitlerinden Mehmed Emin Tokadî’ye yönelik rüya görme yoluyla kurulan iletişim biçimleri ve yaşandığına inanılan olaylar incelenmektedir. Bu memoratların tespiti, yazıya aktarılması bireylere ve kolektif şuuraltına yönelik inanışların geçerliliğinin ve sürekliliğinin devam edip etmediğinin analizi noktasında gerekli ve de önemlidir.

\section{Dinin Uluları: Veliler}

Doğaya karşı çaresizliğinin farkında olan insan; ilkel dönemlerden itibaren karşılaştığ1 zorlukların üstesinden gelebilmek adına manevi bir güce sığınma isteği duymuştur. Bireyler süreç içinde yer-su, güneş, ateş gibi çeşitli nesnelere ve varlıklara kutsiyet yüklemiştir. Ayrıca insanlar, pek çok vasıf atfettikleri kutsal kişilere de korkuyla karışık saygı duymuş, bu kişilere zaman içinde şaman, baksı, veli, şeyh gibi birçok adlandırma yapılmıştır.

Veli, Arapça yakın olmak anlamındaki "v-l-y"den türemiştir. Kelime dostluk, arkadaşlık gibi anlamlara gelmektedir (Çetinkaya, 2010: 77). Nas, kitabında "evliyaları" şöyle açıklamaktadır: "İnsanlara doğru yolu gösterip hal ve hareketleri ile onlara rehberlik etmeleri ahiret sultanlarının en önemli özelliklerindendir. Ayrıca Allah rızası için insanların dertleri ile dertlenmeleri ve fedakârlıkları onların yüce şanındandır. Veliler peygamberlerden sonra seçilenler sınıfındandır. Bir rehber eşliğinde silsile yoluyla Peygamber efendimize kadar gitmeleri; nerede ve hangi memlekette yetişirlerse yetişsinler onları tek bir kaynağa bağlamıştır. Veliler Hak'tan gelen nuru, olduğu gibi yansıtan aynalardır. Hangisine baksak aynı nuru görürüz. Hepsinde o rahmet denizinin izini buluruz..." (Nas, 2018: 20). 
Allah'a yakın olan kişi anlamında "veli” kavramı kullanılmaktadır. Hakk'ın dostu ve sevgili kulu olarak nitelendirilen veliler, sadece bu dünyanın değil manevi âlemin de efendileridir. Farklı mekânlarda aynı zaman diliminde görülebilmekte, yaşamları süresince ve öldükten sonra da insanlara yardım edebildikleri düşünülmektedir. Çözümsüz işlerin nihayete erdirilmesi noktasında insanlar, velilerden medet ummaktadır. Gökyüzünden sofra indirebilen, hastaları iyileștirebilen, zor durumda kalana yetişebilen, mekândan ve zamandan bağımsız olarak hareket eden bu kimseler; keramet gösterme yetisine Allah'ın lütfuyla sahip olduğu düşünülen Allah'ın nadide kulları olarak bilinmektedir.

Velilere yönelik menakıpnamelere bakıldığında; ölüleri diriltme, hayvan formuna girme, hastaları iyileştirme, su üzerinde yürüme gibi pek çok kerametin yer aldığı görülmektedir (Ocak, 1997: 88-92). Yaratıc1 ile hemhal olan bu uhrevi zatlar; akıldan ve kalpten geçenleri bilmekte, az yiyecekle çok kişiyi doyurmakta, bulundukları yere bereket getirmekte, rüyalara vakıf olmaktadır.

Halk muhayyilesi bu zatlara yönelik efsaneler, memoratlar oluşturmaktadır. Bu noktada genellikle tarikatlarca yazılan ve nesilden nesile aktarılan menakıpnamelerin büyük katkıs1 bulunmaktadır. Tanrısal yetkenin taşıyıcısı olan velilerin eşyaları, kabirleri dini açıdan mukaddes kabul edilmektedir. Dini bağlamda değerli kabul edilen insanlara ait kabir, türbe ve yatırlara periyodik ziyaretler yapılmakta, bu ziyaretler esnasında dua etmek, adak adamak, dilek dilemek vb. birçok etkinlik gerçekleştirilmektedir (Parladır, 2010: 187-188). Bu din ulularından biri de Mehmed Emin Tokadî Hazretleridir.

\section{Mehmed Emin Tokadî}

Şehirler medeniyetlerin beşiği olan yerleşim yerleridir. Her şehrin kendine ait bir yazgisı, kimliği ve insanların zihninde bir imajı bulunmaktadır. Şehir hakkında oluşan imaj; insanların o şehre bakış açısını belirlemekte, seyahatten yatırıma kadar pek çok farklı unsuru tetiklemektedir (llıcak ve Aydınalp, 2019: 167). Aynı zamanda şehirleri şehir yapan mimaridir, coğrafyadır, tarihtir ve en önemlisi o şehrin kutsiyet atfettiği velileridir.

Şehirlerin manevi kandilleri olarak nitelendirilen veliler, bazı kentlerde diğerlerine göre daha çoktur. İstanbul da bu sayılı şehirlerden biridir. İstanbul'un fethine yönelik "Onu fetheden komutan ne güzel komutan, o ordu ne güzel ordudur." hadisinden hareketle çok sayıda ordu, âlim ve veli İstanbul'un fethi için uğraşmış, hatta şehir fethedildikten sonra da bu efsunlu şehirde yaşamıştır. Farklı medeniyetlerinde beşiği olan böyle önemli bir şehrin üç büyük evliyasından biri olarak Mehmet Emin Tokadi'nin adı geçmektedir.

Mehmed Emin 1664'te Tokat'ta doğmuştur. Lakabı Cemaleddin, künyeleri Ebu'l-Emâne ve Ebu Mansur, şiirlerinde kullandığı mahlasları ise Emin ve Arif'tir. Mehmed Emin küçük yaştan itibaren babası Hasan'ın da yönlendirmesiyle medrese eğitimi almıştır. Mehmed Emin'in ilk ve ileri düzey medrese tahsilini Tokat'ta gerçekleştirdiği bilinmesine rağmen hangi medresede ve kimlerden ders aldığına dair kesin malumat mevcut değildir. 1688'de İstanbul'a gelen Mehmed Emin Tokadî, Zeyrek yokuşundaki Piri Paşa Medresesi'ne yerleşmiştir. Şeyhülislam Mirzazade Muhammed Efendi ve onun yanındaki zatlardan İslami ilimlere dair eserleri okumuş, Yedikuleli Abdullah Efendi'den hat dersleri almıştır. Kendisi bazı talebelere dini ve edebi eserleri okutmuştur (Şimşek, 2012: 390).

Kesedar Ali Efendi 1702 'de Edirne'de görevlendirildiğinde oğluna ders vermesi için Mehmed Emin'i de beraberinde götürmüștür. Burada tanıştı̆̆ı musiki üstatları Buhûrîzâde Mustafa Itrî Efendi, Küçük Müezzin Mehmed Efendi ve Yahyâ Nazîm Çelebi'den musiki dersleri almıştır. Birkaç ay sonra Ali Efendi'nin oğlu vefat etmiş bunun üzerine Kadirî şeyhi Mehmed Efendi ona hacca gitmesini tavsiye etmiştir. Mekke'de bulunan Ahmed Yekdest-i Cüryânî'ye selâmını da götürmesini belirtmiştir. Ahmed Yekdest-i Cüryânî ile tanıştıktan sonra hayatında yeni bir dönem başlamıştır (Şimşek, 2003: 467). 
Ahmed Yekdest-i Cüryânî'nin hem sohbetlerini takip etmiş hem de onun aracılı̆̆ıyla tasavvufi terbiyesini tamamlamıştır. 1705'te şeyhinin talimatıyla İstanbul'a dönmek üzere yola çıkmıştır (Şimşek, 2012: 392-393). Mehmed Emin Tokâdî, Ahmed Yekdest-i Cüryânî’nin bilinen İstanbul'a ulaşan üç halifesinden biridir (Kara, 2006: 53). Mehmed Emin, Nakşibendi'ye dişında diğer tarikatlardan da icazet almıştır (Şimşek, 2012: 392-393). Bu onun dönemine göre ne kadar açık ve ileri görüşlü biri olduğunun kanıtıdır. Farklı tarikatlar ona farklı bakış açıları kazandırmış, onun kişisel gelişimine katkı sağlamıştır.

Mehmed Emin Tokadî Hazretleri, tekke şeyhi olmadan senelerce irşat faaliyetlerini sürdürmüştür. Şeyhülislâm Mustafa Efendi, 1743'te Ayvansaray'daki Emîr Buhârî Tekkesi'nin şeyhi Kırımlı Ahmed Efendi vefat edince bu tekkenin şeyhliğini Mehmed Emin Tokadî’ye teklif etmiştir. Mehmed Emin, bu teklifi tekkede ikamet etmemek şartıyla kabul etmiştir. 12 Eylül 1745 'te ölmüş ve Zeyrek’te Pîrî Paşa (Soğukkuyu) Camii Kabristanı'na defnedilmiştir (Şimşek, 2003: 467).

Mehmed Emin Tokadî’nin Zeyrek Yokuşu'ndaki kabrinin kolay bulunamaması çoğunluk tarafindan bilinen bir hadisedir. İstanbul'un önemli manevi duraklarından biri olan bu mekânı, her gün yüzlerce kişi ziyaret etmekte, oraya sadece davet edilenlerin gittiği düşünülmektedir. Bunda Mehmed Emin Tokadî"ye izafe edilen "kabrine gelip Fatiha okuyanın, cehennem ateşinde yanmaması" konusunda ettiği duasının da etkili olduğu söylenmektedir. Mehmed Emin Tokadî’ye yönelik olarak halk arasında pek çok efsane ve memorat oluşmuş ve farklı anlatılar da aktarılmaya devam etmektedir. Bu çalışmada Mehmed Emin Tokadî’ye yönelik zuhur etmiş memoratlar üzerinde durulacaktır. Akla ister istemez memorat nedir sorusu gelmektedir.

\section{Memorat Kavramına Dair}

Kişinin gerçekleştiğine inandığı, realiteye yönelik izahı tam olarak yapılamayan olağanüstülüklerle örülü anlar ve olaylar memoratları meydana getirmektedir. Şahsi bir deneyim ürünü olan bu yaratımlar; içinde kendinden daha büyük bir güce sahip olduğu düşünülen varlığa yönelik saygıyı, kolektif şuuraltıyla oluşturulan kültürel kodları barındırmaktadır.

Memorat "tabiatüstü ferdî bir tecrübe yaşayan veya ondan dinlemiş birisi tarafindan anlatılan şahsa bağlı hikâye" (Çobanoğlu, 2003: 21) şeklinde tanımlanmaktadır. Burada yer alan "tabiatüstü”lük aslında "öteki dünya" ve farklı bir boyutta olmanın yanı sıra cin, peri, şeytan, alkarısı, karabasan gibi varlıklarla yapılan konuşma, dokunma, rüya gibi yollarla kurulan iletişim durumudur (Çobanoğlu, 2003: 21). Öteki dünya, farklı boyut durumları insanları bir yandan korkuturken; bir yandan bilinmeze yönelik duyulan büyük merak, tabiatüstü varlıklarla gerçekleşen spritüal deneyim olgusu, kişiyi ister istemez cezbetmektedir.

Memorat kavramı sözlükte "yaşanıldığına inanılan metafizik bir hadisenin kendisi veya bir başkası tarafından anlatılan hikâyeye verilen ad" (Kaya, 2007: 512) olarak tarif edilmektedir. Gürol Pehlivan ise memoratı 'inanç anısı' kavramıyla açıklamaktadır (Pehlivan, 2009: 91). Yani memorat "inancı" var olma sebebinde barındırmaktadır. Her gerçekleşen memorat, onu tecrübe eden kişi tarafından yaşanıldığına inanılan doğaüstü bir gerçekliktir. Bu yaratımlar bir yandan tekinsiz bir yandan da herkesin yaşayamayacağı efsunlu ürünlerdir. Bunların anlatılması zor, başkalarına inandırılması ise yoğun emek isteyen bir süreç içermektedir.

Von Sydow'un farklı bir efsane çeşidi olarak gördüğ̈̈ memorat1, Juha Pentikäinen kendine has bir tür olarak kabul etmektedir (Çobanoğlu, 2003: 21). Memoratlar efsanelerin alt başlığında yer mi almalı yoksa ayrı bir tür olarak kabul edilip incelenmeli mi gibi tartışmalar yaşansa da memorat, ayrı bir tür olarak halkbilimi kadroları arasında yerini almış bulunmaktadır (Koç, 2012: 269). Honko’ya göre memoratlar göz ardı edilmiş geleneksel bir türdür (Dégh ve Vázsonyi, 2015: 132).

Balaban'a göre efsane düne memorat ise bugüne aittir. Memorat bireysel tecrübeye, efsane nakle dayanmaktadır. Her iki türde de hadisenin geçtiği yer yaklaşık olarak belirlenebilmektedir. "İnanma" her iki tür için de ortak bir tavırdır. Memoratın da efsanenin de gerçek olduğu 
düşünülmektedir. Memorat ve efsane kahramanları insanlar veya cin, peri, ruh gibi soyut varlıklar olabilmektedir (Balaban, 2013: 53-55). Pehlivan, efsane ile memorat türü arasındaki ayırt edici ölçütleri inanç şiddeti, tecrübe ve de zamansallık şeklinde vurgulamaktadır (Pehlivan, 2009: 95).

Özkul Çobanoğlu memoratlara yönelik en önemli çalışmalardan birini gerçekleştirmiştir. "Türk Halk Kültüründe Memoratlar" adlı kitabında memoratların çeşitlerini şöyle sıralamaktadır:

I) Cinler İle Kurulan İletişim Biçimleri ve Yaşadığına İnanılan Olaylar

II) Alkarısı İle Kurulan İletişim Biçimleri ve Yaşandığına İnanılan Olaylar

III) Ağırlık Basması-Karabasan, Congoloz, Kul, Erkebit, Hırtik, Hınkur Munkur, Çarşamba Karısı, Yol Azdıran, Kara Ura, Demirkıynak ve Gelincik Adlı Varlıklarla Kurulan İletişim ve Yaşandığına İnanılan Olaylar

IV) Hızır ile Kurulan İletişim Biçimleri ve Yaşandığına İnanılan Olaylar Olaylar

V) Yatırlar, Evliyalar ve Şehitlerle Kurulan İletişim Biçimleri ve Yaşandığına İnanılan

VI) Rüya Görme Yoluyla Kurulan İletişim Biçimleri ve Yaşandığına İnanılan Olaylar

VII) Nazar Değmesi İnancıyla İlgili İletişim Biçimleri ve Yaşandığına İnanılan Olaylar

VIII) Ölülerle Kurulan İletişim Biçimleri ve Yaşandığına İnanılan Olaylar Olaylar

IX) Büyü ve Çeşitli Geleneksel Pratikler Yoluyla Kurulan İletişim ve Yaşandığına İnanılan

X) Fal ve Falcılık Yoluyla Kurulan İletişim Biçimleri ve Yaşandığına İnanılan Olaylar

XI) Tam Tanımlanamayan Olağan Üstü Bir Güçle Kurulan İletişim ve Yaşandığına İnanılan Olaylar

XII) Modern Kent Yaşamı Memoratları: Ruh Çağırma, Astral Yolculuk ve Ufo'larla Kurulan İletişim Biçimleri ve Yaşandığına İnanılan Olaylar (Çobanoğlu, 2003: 77-82).

$\mathrm{Bu}$ çalışmada Mehmed Emin Tokadî’ye yönelik rüya görme yoluyla kurulan iletişim biçimleri ve yaşandığına inanılan olaylar incelenecektir. Memoratlar genelde uykuyla uyanıklık arasında ya da rüya esnasında gerçekleşebilmektedir.

\section{Yarı Bilinçlilik Hali: Rüya}

Dünyadaki hayatının neredeyse üçte birini uykuda geçiren insanoğlu için rüyanın önemli bir yeri vardır. İnsan doğumdan ölüme kadar rüya tecrübesini milyonlarca kez deneyimlemektedir. Ruhun gördüğü aklın ise idrak ettiği farklı bir âlem, yepyeni gizli bir dünyadır rüya. Rüya hem reel hem doğaüstü bir gerçekliktir; rüya bedenden azade zincirleri kıran bir özgürlük, rüya bir benlik aynı zamanda bir hiçlik halidir. Rüyalar yol göstermekte, rüyalar halden anlamakta, rüyalar âdeta fisıldamaktadir.

Rüya; uyku esnasında görülen birtakım olaylara verilen, Arapça "rü’yâ" kökünden "düş görmek" anlamına gelen bir kelime şeklinde açıklanmaktadır (Tatçı ve Çeltik, 1995: 13). Rüya "Misal âlemindeki kaderle alakalı levhaların, aynen veya değişik yansımalar halinde uyku halinde ruhumuza aksetmesidir." diye de tanımlanmaktadır (Köksal, 2008: 36).

Yüzyıllardan beri insanda merak duygusu uyandıran rüya mefhumu, anlamlandırılmaya çalışılmaktadır. Dünya üzerinde kurulan bütün medeniyetlerde, inanılan neredeyse bütün dinlerde ve de inanç sistemlerinde rüyaya yönelik çeşitli bilgilere ulaşmak mümkündür. 
Babilliler ve Asurlular başları sıkıştıklarında rüya tanrıçası Mamu'dan yardım isterken (Günay, 1999: 80), Afrikalılar tanrılarının ve atalarının rüyalarına girerek kendilerine rehberlik ettiğine inanır (Moran, 1961: 34). Yunanlılar ise hayatlarını -üç çeşit olduğunu düşündüklerirüyalara göre düzenlemektedir (Parman, 2001: 28).

Üç semavi dinin kutsal kitabında rüyalara, rüyalarla temellendirilmiş kıssalara yer verilmiştir. Tevrat, İncil ve Kur'an-1 Kerim'de rüyalardan bahsedilmektedir. Hz. Yusuf'un rüyası ise özellikle bilinen rüyalardan biridir. Ayrıca Kur'an-1 Kerim'de Hz. Muhammed'in ve Hz. İbrahim'in rüyaları da geçmekte, hatta rüya tabiri ilimden bahsedilmektedir.

Rüya, insanoğlunun hem psikolojik hem de fizyolojik ihtiyaçlarından biridir. Rüyanın doğal, günlük biyokimyasal bir süreç olduğu kanıtlanmıştır (Gonzalez, 2007: 30). İnsan yaşamının vazgeçilmez bir parçası olan rüyalar; biyolojik, psikolojik, fizyolojik, sosyolojik açıdan önemlidir. Tarih boyunca insanlar; rüyaların ilahi âlemle, bilinmeyenle ilişkili olduğuna inanmış, rüyada gördüklerinden geleceğe yönelik anlamlar çıkarmaya çalışmıştır.

Doğu ve Batı bilginleri rüyaya farklı şekilde yaklaşmıştır. Batı bilginleri genelde rüyayı insanın günlük yaşantısının yansıması olarak yorumlamıştır. Doğu bilginleri ise bu görüş̧e katılmakla birlikte; rüyayı, Allah'tan gelen ilahi bir mesaj olarak da kabul etmişlerdir (Güven ve Belbağı, 2006: 19).

Farabi'ye göre rüya uyanıkken duyma, düşünme ve irade güçlerinin etkisinde kalan hayal gücünün; uykuda bu etkilerden kurtularak faaliyet göstermesiyle ortaya çıkmaktadır (Peker, 2003: 40). İbn Haldun rüyanın ruhani bir şey olduğunu düşünmektedir. Uyku esnasında ruh, ten ve maddi şeylerle olan ilişkisini kesmekte; mana âlemine dalmakta, gaipten kendisine akseden varlıkların şekil ve suretini görmektedir (Merter, 2008: 324-325).

İbn-i Sina uyuyan bedeninin ölülere benzer bir hal aldığını iddia etmektedir. Uyku halinde bazı şeylerin görüldüğünü, işitildiğini hatta sadık rüyalarda, uyanıkken elde edilemeyecek bilgilerin ilham edildiğini vurgulamaktadır (İmamoğlu, 2004: 18). İmam Gazali hadislerden hareketle rüyanın aslı itibariyle peygamberliğin nurlarından olduğunu belirtmektedir (Yüksel, 1996: 138). İmam Gazali’nin yorumuyla bazı rüyalar, dini açıdan çok mühim bir yerde konumlandırılmaktadır.

Sokrates rüyaları insanın vicdanına dair bir ses olarak değerlendirmekte ve insanların bu sesi ciddiye alıp, ona uymaları gerektiğini ileri sürmektedir (Fromm, 1990: 133). Aristo ise rüyaların genellikle bir anlam içermediğini öne sürmektedir. Ona göre rüyaların birçoğu, rastlantı sonucu oluşmaktadır. Geleceği önceden görme gibi bir işlevi de bulunmamaktadır (Fromm, 1990: 137).

Rüyaya yönelik çok önemli araştırmalar yapmış olan Sigmund Freud; rüyaları, uyuyan kişinin uyuduğu süredeki ruhsal etkinliği olarak tanımlamaktadır (Freud, 2011: I, 7). Freud, rüyaları akıl dışı bir ürün olarak görmektedir. Gelecekten haber verme özelliğine sahip olmayan rüyalar, geçmiş hakkında bilgi vermekte ve geçmişten kaynaklanmaktadır (Freud, 2011: II, 390). Sigmund Freud rüyaları ilahi bir kaynağa bağlamamıştır. Rüyaları bilinçaltındaki arzuların ve isteklerin ortaya çıkmasına elverişli bir ortam olarak değerlendirmiştir. Hatta Freud rüyalardaki pek çok unsurla cinsellik arasında bağlantı kurmuştur. Doğu bilginleri rüyayı mistik ve dini bir unsur olarak değerlendirirken, Batı bilgileri ise daha akılcıl ve insanın bilinçaltından hareketle yorumlamışlardır.

Bilinmezi bilmek isteyen insanoğlu; rüyalar aracıllğıla gaybtan haber alabileceğini düşünmüş, istiharelere yatarak yapacakları seçimleri veya yaşadıkları olayların hayır $\mathrm{m}$ şer mi olduğunu anlamaya çalışmış, ilahi varlıkların rüya esnasında kendileriyle iletişim kurulduğuna inanmıştır. Bu araştırmada da Mehmed Emin Tokadî’ye yönelik rüya görme yoluyla kurulan iletişim biçimleri ve yaşandığına inanılan olaylar memorat çeşitleri değerlendirilmiştir. 


\section{Mehmed Emin Tokadî Memoratları}

Mart-Haziran 2019 tarihlerinde yönlendirilmiş mülakat yöntemiyle sahada derleme çalışması gerçekleştirilmiştir. Araştırmanın malzemesini oluşturan ve sahada derleme yoluyla tespit edilen altmış anlatının yirmi ikisini memorat türündeki anlatılar teşkil etmektedir. Bu memoratlardan on beşi rüyalar etrafından teşekkül eden memoratlardır. Bu kısımda kaynak kişilerden derlenen, Mehmed Emin Tokadî hakkında meydana getirilen memorat metinleri verilecektir. Kaynak kişilerin pek çoğu memoratların gerçek hayatla bağlantılı olduğunu, yaşadıkları olaylarla realitede memoratların gerçekliğinin onaylandığını ileri sürmektedir.

1. 'Üniversitede okurken bir hocamız İstanbul'daki yatırlarla ilgili ödev vermişti. Türbeye gideceğimiz günün gecesi rüyamda bir zatı gördüm. Beni çağırıyordu ama neresi olduğunu söylemiyordu. Öteki gün biz iki arkadaş ödevi yapmak için yola çıktık. İstanbul'un yabancısıyız o zaman. Yanlış otobüse binip yanlış durakta indik. Aslında başka bir zatı arıyorduk. Yolda gördüğümüz kişiler, bizi doğru dürüst dinlemeden siz şurayı arıyorsunuzdur diye bizi Mehmed Emin Tokadî Hazretlerinin makamına yönlendirdi. Geldik bir baktık bu kişi de önemli bir zat. Diğer zatı değil gelmişken bu zatı çalışalım dedik. O zaman burada küçük bir çilehane gibi bir yer vardı. M. Emin Tokadî burada ibadet ediyormuş, ney üflüyormuş. Öyle anlattılar. Biz iki arkadaş buraya girdik bir kadınla tanıştık. O zaman kayıt cihazıyla kadının anlattıklarını kayda aldık. Mehmed Emin Tokadî'nin duasını öğrendik. Eve geldik kaydı ödeve aktaracağız dinlemeye başladık. Kayıt sırasında o çilehanede "ney sesleri" vardı. Çok güzel ney çalınıyordu. Dehşete kapıldık. Seslere inanamadık çünkü biz oradayken ney çalan hiç kimse yoktu. Zaten küçücük bir yer. Hiç ses yoktu. Zatın bizi özellikle çağırmış olduğunu anladık.” (K15)

$\mathrm{Bu}$ anlatıda da kaynak kişinin Mehmed Emin Tokadî’yle rüyalar aracılığıyla iletişim kurduğu düşüncesine sahip olduğu görülmektedir. Hatta gerçek hayatta yaşadığ 1 aksilikleri ve yanlışlıkları, Mehmed Emin Tokadî’nin vesile olduğu ilahi bir duruma bağlamaktadır. Başına gelen olağanüstülük ile zatın kendisiyle münasebet kurduğundan emin olmaktadır.

2. "Zatın duasını öğrenince ailece zatı ziyarete gelmeye karar verdik. Yola çıkacağız Silivri'den geliyoruz biz. Silivri'de sel oldu gelemedik. Aradan bir süre geçti. Tekrar ailece gelmeye niyet ettik. Bu sefer de İstanbul'da bir elektrik kesintisi öyle böyle değil. Yine ziyaret edemedik. En sonunda ailece arabayı bindik gelmeye. Arabanın tekerleği patladı. Biz yine gelemedik. Zat bizi kabul etmedi. Sonra rüyama girdi zat, beni çağırdı türbeye. "Tek gel" dedi. Ben tek başıma onu ziyaret edebildim.” (K2)

$\mathrm{Bu}$ anlatıda zatın bütün ailenin değil sadece kaynak kişinin ziyaretini kabul etmesi durumu vurgulanmaktadır. Mehmed Emin Tokadî kaynak kişinin rüyasına girerek sadece onu huzuruna kabul edeceğini belirtmiş ve kaynak kişi, pek çok başarısız denemeden sonra bu rüyanın ertesinde türbeye gidebilmiştir.

3. "Benim kızım yıllarca üniversiteyi kazanamadı. Tabii bu duruma hepimiz çok üzüldük. Bir gece rüyamda bir kişiyi gördüm. Böyle beyazlar içinde, uzun boylu bir erkek. Bana adının Mehmed Emin Tokadî olduğunu, kızımın üniversiteyi kazanacağını söyledi. Hatta sonra kızın ile beni ziyaret et, namaz kıl dedi. Gerçekten de kızım üniversiteyi rüyadan sonra kazandı. O zamandan beri türbeye hep geliriz." (K13)

Burada da Mehmed Emin Tokadî’nin, kaynak kişiye müjdeli bir haber verdiği ve bu haberin şükrünü eda edebilmesi için kendisini ziyaret etmesi gerektiği durumunu vurguladığı görülmektedir. Zat tarafından iletilen haber realitede de gerçek olunca, kaynak kişi zatın kendisini beklemekte olduğu inancını geliştirmiş̧ir.

4. "Önce duasını duydum, niyetlendim gelmeye. Ama yıllarca olmadı. Sonra rüyamda da gördüm. Zat beni çağırıyordu. Üstüne bir de askerliğim buraya çıkınca gideceğim, göreceğim dedim. 
Rüyamda da şu şekilde görmüştüm. Yokuşun başına geldiğimde sağdan çıkmam gerekirken soldaki merdivenden yanlış yere çıkmıştım. Orada yeşillik, toprak bir alan vardı. Orada oturdum, dua edeyim dedim. Sonra insanlar yanlış yerde olduğumu söyleyip doğru yeri tarif ettiler bana rüyamda. Sonra buraya geldiğimde de gerçekten öyle oldu, aynı rüyamdaki gibi." (K10)

Anlatıya bakıldığında kaynak kişinin Mehmed Emin Tokadî’yle rüya aracılığıyla iletişim kurduğuna inandığı hatta gerçek hayatta rüyasında gördüğüne benzer bir olay yaşamasıyla bu iletişimin gerçekliğinden "emin” olduğu anlaşılmaktadır.

5. "Ben ziyarete gelmiştim. Bir işim çıktığı için geri dönmüştüm. Sonra zat rüyama girdi, bana niçin gelmedin dedi. Kapıda havlun hazırdı dedi. E ben şimdi yaşlıyım buradaki yokuş da bana çok zor gelmişti ben de geri dönmüştüm. Rüyamda "Niye geri döndün?" dedi ve benim nasıl geri döndüğümü bildi. Çok etkilendim. Bunun üzerine türbeye tekrar gitmeye karar verdim.” (K3)

Kaynak kişi burada, gerçek hayatta yaşadığı durumun; Mehmed Emin Tokadî tarafindan bilindiğini, rüya yoluyla kendisine bildirildiğini düşünmektedir.

6. "Rüyamda yüzünü göremedim arkası dönüktü. Üzerinde beyaz bir elbise gibi gömlek gibi bir şey vardı. Benim elimde de bir Kur'an vardı. Yanına gitmek istedim ama gidemedim. Bir yerden de ezan sesi geliyordu. Sonra uyandım. Gerçekten de sonra türbeye gelmek için birkaç defa uğraştım ama gelemedim. Şimdi nasip oldu. Ama sanki o rüyadan sonra her şey daha güzel oldu.” (K11)

$\mathrm{Bu}$ anlatıda da kaynak kişi, rüyasında zatın yanına gidememesi olayıyla realitede türbeyi bir türlü ziyaret edememesi arasında bağ kurmuştur. Bu durumun zat aracilığıyla kendisine ilham edildiğini farz etmektedir.

7. "Bu türbeye gelmeden önce türbe nerede diye düşündüm. Rüyamda türbeyi gördüm. Ama yerini tam bulamıyordum ve Mehmed Emin türbeyi bulmamda bana bir şekilde yardım ediyordu. Daha sonra ertesi gün arkadaşımla türbeyi aramaya çıktık. İnsanlara soruyoruz ama kimseden net bir cevap alamıyoruz. Neyse yolda yürürken karşıdan bize doğru bir adam geliyordu. Tam soruyu soracaktık ki adam bize "Aradığınız yer şu yokuşun solunda dedi." Biz tabi o anlık kafayla teşekkür edip yola devam ettik. Biz daha soruyu sormadan tarif etmişti. Durumu fark edip arkaya dönmemiz bir oldu. Geri döndüğümüzde o adam yoktu. İlahi bir yönlendirmeyle türbeyi bulduk. Açıkça söylemem gerekirse çok tırstım. Tüylerim hala diken diken.” (K7)

Kaynak kişi Mehmed Emin Tokadî’nin vesile olduğu manevi bir yönlendirmeyle türbeyi bulduğuna inanmakta, hatta yaşadığı bu deneyimden oldukça korkmaktadır.

8. "Buraya gelmeden önce rüyamda bembeyaz saçlı yaşlı birisini gördüm. "Beni takip et!" diyordu. Ben de takip ettim. Uzun bir süre onun arkasından gitmeye devam ettim. En sonunda bir kabristana geldik. Etraf yemyeşil çiçeklerle doluydu. Burası neresi diye sorduğumda bana hiç cevap vermedi. Etrafi gezmeye başladık. Ama sanki cennetten bir bahçe gibiydi. Kuşların cıvıltısı, çiçeklerin kokusu. Her şey çok güzeldi. Uyandıktan sonra bunu bir imama anlattım ve beni buraya yönlendirdi. Rüyamda gördüğüm kişinin Mehmed Emin Tokadî olabileceğini söyledi. Türbeye gelince rüyamda gördüğ̈̈m yerle aynı olduğunu gördüm. $O$ günden beri elimden geldiğince gelmeye devam ederim." (K1)

$\mathrm{Bu}$ anlatıda kaynak kişi, bir din adamına danışarak rüyasını anlatmış ve onun yorumuyla Mehmed Emin Tokadî’nin türbesini ziyaret etmiştir. Türbeye geldiğinde rüyasında kendisine gösterilen yerle aynı olduğuna emin olmuş ve bu ilahi yönlendirmeden de hareketle türbe ziyaretlerine devam etmişstir.

9. "Ben zatı Tokat'ta yatıyor zannetmiştim. Sonra kardeşim onu ziyaret ettiklerini söyledi. Ben de dedim ki "Nasıl gittiniz Tokat'a?" O da dedi ki "Hayır çok yakında." Bunun üzerine türbeye gitmeye karar verdim. Rüyamda gördüm buraya gelmişim yeşil bir çadır kurulu. Mübarek bir zat herkese elini öptürüyor. Sonra diyor ki görevlilere söyleyin buraları düzenlesinler diye. Tam 
kaybolacağı sırada M. Emin Tokadî’yim diyor kayboluyor. Buraya bir geldim ki hakikaten yeşil yeri. Rüyamda gördügümün aynısı. Ama türbeyi de çok zor bulduk. Hatta yolda karışık olaylar geldi başımıza. Kanlı bıçaklı olaylar bile oldu. Meğer duası varmış herkes bulamasın diye.” (K8)

Yine burada da rüyada olan mekânla, realitede Mehmed Emin Tokadî’nin türbesinin aynı olması durumu vurgulanmaktadır. Kaynak kişi türbeyi bir türlü bulamaması durumunu da ilahi bir olguyla "dua" ile ilişkilendirmiştir.

10. "Bir gün rüyamda gördüm. Buraya gelmişim kızım için ağlıyordum. Bilmiyorum o sıralar burayı. Kızımla da bir sorunum yoktu. Ağlarken mescitteyim. Tabi başımı duvara dayamışım. Bir baktım karşımda uzun boylu bir hoca kamet getirmeye hazırlanıyor namaz kıldırmak için. Hemen kendimi toparlıyorum. Yanımda biri vardı, çocuktu. Hatta böyle top yüzlü süt beyazı soruyorum işte yavrucağa "Ne oluyor canım burada diye?". Çocuk da bana "Mehmed Emin Efendi namaz kılmaya geldi teyze. Acele et de geç kalmayalım." diyor derken uyandım. Zatın beni çağırdığını anladım. Rüyamda tabii yüzünü görmedim sadece arkasından gördüm. O bile bana yetti.” (K9)

Kaynak kişi Mehmed Emin Tokadî’nin kendisiyle iletişim kurarak, onu türbesine çağırdığına inanmaktadır. Hatta zatın yüzünü görmemesine, sadece arkasından onu görmesine rağmen bu kişinin Mehmed Emin Tokadî olduğundan emindir.

11. "Tokadî Hazretlerinin türbesinin yerini öğrendim. Hep bir gün gidicem diye niyet ettim. Bugün dedim, yarın dedim derken bir türlü nasip olmadı. Demek ki daha nasibim yoktu. Çünkü diyor ya nasibi olan gelsin. Ve günlerden bir gün bir rüya gördüm. Şimşek hızıyla bir at arabası geliyor. Çok güzel bir yoldayım. At arabasına biniyorum. "Nereye gidiyoruz?" diyorum. Bir türbeye götürüyor beni ama ben türbe kimin bilmiyorum. Gidiyorum, gidiyorum. Aaa diyorum Tokadî’nin türbesi değil mi burası? Herkes evet diyor. Türbeye gidip dua edeceğim bir ses geliyor. Bana diyor ki "Zeycan hoş geldin. Biz seni çağırmadan buraya gelmeyi bilmiyor musun?" Arkamı dönüyorum sarıklı, uzun boylu fidan gibi bir yiğit. Sarığı da yandan aşağı sarkmış. Tabii yüzünü göremiyorum. Cübbesini, sarığını görüyorum. "Ya Tokadî diyorum çok istiyorum türbene gelmeyi ama nasibim olmuyor." diyorum. "Nasibimde ne zaman var, ne zaman gelcem?" diyorum. "Geldin ya Zeycan" dedi. "Nasibin oldu, geldin işte." Rüyadan iki gün sonra yoldayım arkadaşım da yanımda. Fatih Camisine gittik, ferace baktık. Yolumuzu kaybettik. Bir baktık yolda bir ok işareti Tokadî Hazretlerine gider yazıyor. Ve kendimi Tokadî Hazretlerinin yanında buldum. Niyetle olmadı, tesadüfen gittik. Rüyamdan iki gün sonra." (K4)

Burada da yine Mehmed Emin Tokadî'nin kaynak kişiyle, rüyada yaşandığına inanılan olaylar aracılığıyla münasebet kurduğu görülmektedir. Zat hem kendini göstermiş hem de kaynak kişiye türbesine gelerek onu ziyaret edeceği ve bu ziyaretin kabul olduğu bilgisini vermektedir.

12. "Rüyamda türbenin temizliğini yapıyorum. Orada delikte bir 1ş1k gördüm. Delikten bir 1şık, bir kıvılcım çıktı. Ezan okununca kendi kendine büyüdü. Yumurtadan fazla büyüdü. Bismillah salavat çektim. Bir nur ilahi bir nur. Âdeta buraya gelmemi istiyor, beni çağırıyor. Zatın beni çağırdığını anladım geldim öteki gün buraya. Işı̆̆ın çıktığı yere baktım aynı rüyamda gördüğüm gibi. Baktım orada bir şey yoktu çok güzeldi ama." (K5)

Bu anlatıda kaynak kişi Mehmed Emin Tokadî’nin ilahi bir nur aracılığıyla kendisini çağırdığııı düşünmektedir.

13. "Burası geçen geldiğimde kapalıydı. Kapılar kilitliydi giremedim. Akşamüzeri uçağım vardı. Kısmet olmadı. Sonra zatı rüyamda gördüm. Tekrar gelmemi söylüyordu, beni çağırıyordu. Bak ablam şahit. Yine geldim. Bu sefer zatı, türbeyi ziyaret edebildim. Zaten zat herkesin onu bulmasını istemiyormuş. Beni çağırdı, benim ziyaretimi kabul etti." (K14) 
Kaynak kişi ilk ziyaretinin zat tarafından uygun bulunmadığını, bu yüzden türbeye giremediğine inanmaktadır. Sonrasında Mehmed Emin Tokadî’nin onunla rüya aracılığıyla iletişim kurarak ziyaretini kabul edeceği bilgisini verdiğine itimat etmektedir.

14. "Rüyamda mezarının sağındaki merdivenleri ve bahçesini görmüştüm. O merdivenlerden inip bahçede oturup manzarayı seyredip bir şey bekliyordum. Sonra bir erkek sesi duydum. Benim onu ziyarete gelmemi söylüyordu. Ama yüzünü göremedim. Sadece sesini duydum. Bu rüyadan sonra şans eseri ailemle buraya geldik. Rüyamda gördüğüm yer olduğunu anladım. Evliyanın beni burada beklediğini düşündügüm için dua etmeye tekrar tekrar geldim." (K6)

Burada da yine kaynak kişinin, zat tarafından türbeyi ziyarete çağırıldığına inanması durumu söz konusu edilmektedir.

15. "Ben burayı ilk bulmaya çalıştığımda o kadar gezip aramama rağmen bulamamıştım. Sonra bir rüya gördüm. Yine gelmişim buraya ama türbeyi bulamıyorum. O esnada biri bana yolu tarif ediyor sonra kayboluyor. Aradan baya zaman geçtikten sonra yolum yine buraya düştü. Aklıma rüya geldi ve yeniden türbeyi aramaya başladım. Ararken tanımadığım birisi yanıma gelip "Baktığın yerin sol tarafinda yukarısı" dedi, gitti. Adam benim burayı aradığımı nerden biliyordu bilmiyorum. Onun tarifiyle rüyadaki gibi türbeyi buldum. Bu olaydan sonra buraya gelmek nasip oldu." (K12)

Kaynak kişi diğer anlatılarda da olduğu gibi burada da Mehmed Emin Tokadî'nin vesile olduğu ilahi bir yönlendirmeyle türbeyi bulduğuna inanmaktadır.

\section{Sonuç}

Üstün vasıfları sebebiyle Allah dostu olarak kabul edilen velilere; insanlar tarafindan hürmet gösterilmekte, saygı duyulmaktadır. Bu seçkin kullar; inanışa göre bazı insanlara yardım edebilmekte, onların sıkıntılarını giderebilmekte çeşitli lütuflarda bulunabilmektedir. Mehmed Emin Tokadî de İstanbul'un önemli velilerinden biri olarak bilinmektedir.

Bazı şehirler yüzyıllar içinde ilmin, bilimin ve dinin cazibe merkezi haline gelmiştir. Konya, Urfa, Amasya ve özellikle İstanbul denildiğinde çoğunlukla dini açıdan ünlü zatlar hatırlanmakta ve bu kentler bilhassa bu özellikleriyle anılmaktadır. Mehmed Emin Tokadî de İstanbul şehrine güzellik katan, manevi ruhunu meydana getiren mühim bir şahsiyet olarak zikredilmektedir.

Mehmed Emin Tokadî'nin makamı Zeyrek Yokuşu'nda yer almaktadır. Her gün yüzlerce insan, Tokadî Hazretlerini ziyaret etmekte ve hayır duasına erişmek amacıyla farklı ilçelerden farklı şehirlerden hatta farklı ülkelerden gelmektedir. "Edeple gelen lütuf ile gider." diye yazılan bu mekân, Mehmed Emin Tokadî'ye izafe edilen "kabrine gelip Fatiha okuyanın, cehennem ateşinde yanmaması" duası sebebiyle de insanların görmek istediği bir yerdir.

Dinin ulularından biri olan Mehmed Emin Tokadî’ye yönelik pek çok efsane, menkıbe ve memorat meydana getirilmiş hala da meydana getirilmeye devam etmektedir. Bu çalışmada Mehmed Emin Tokadî hakkında oluşturulmuş memoratlar üzerinde durulmuştur. Tabiatüstü ferdi tecrübeye dayanan, şahsa bağlı hikâyeler olan memoratlar; tekinsiz, gizemli ve aynı zamanda büyülü ürünlerdir. İçinde barındırdığı doğaüstü olgular sebebiyle insanlarca paylaşılması, anlatılması, inandırılması zor olan deneyimlerdir. Memoratlar genellikle uyku ile uyanıklık arasında, rüya esnasında gerçekleşmektedir.

Velilerin gizemli bir dünya olan rüyalar âleminde, kendi seçtikleri özel kişilerle iletişim kurduklarına inanılmaktadır. Jung; rüyaların arzu ve istekler dışında korkuları, irrasyonel tecrübeleri, ilahi mesajları vb. içerebileceğini düşünmektedir. Memoratlarla bu irrasyonal tecrübe gerçekleşmekte, dini açıdan önemli kişilerden ilahi mesajlar iletilmektedir. Rüyaların ruhsal dengeyi sağlama fonksiyonları sayesinde bu tarz tecrübeleri yaşadıklarını iddia eden insanlar; biyolojik ve ruhsal dengelerini restore etmektedir. $\mathrm{Bu}$ açıdan rüyaların insan hayatı için mühim yeri bulunmaktadır. Rüyalar aracılığıyla kişiler, pek çok farkındalığa davet edilmektedir. 
Araştırmanın konusunu Mart-Haziran 2019 tarihlerinde derleme çalışmasıyla elde edilmiş on beş memorat oluşturmaktadır. Bu memoratlar Özkul Çobanoğlu'nun "Türk Halk Kültüründe Memoratlar" adlı kitabında gerçekleştirdiği tasnifte yer alan "Rüya Görme Yoluyla Kurulan İletişim Biçimleri ve Yaşandığına İnanılan Olaylar" sınıflandırmasına girmektedir. Mehmed Emin Tokadî Türbesi’nde kaynak kişilerden derlenen bu bölümlemeye uygun memoratlara bakıldığında kaynak kişilerin büyük bir kısmının memoratların gerçek hayatla bağlantılı olduğuna inandıkları görülmektedir. Kaynak kişiler başlarından geçen olaylar ve anlarla realite de memoratların gerçekliğinin onaylandığını iddia etmektedir.

Kaynak kişiler Mehmed Emin Tokadî’yle rüya esnasında iletişim kurduklarına inanmaktadır ve zatın kendilerini özellikle ziyaretine çağırarak lütuflandırdığını, makamına kabul ederek şereflendirdiğini düşünmektedir. Tokadî Hazretleri bazen geleceğe yönelik müjdeler vermiş bazen de keramet göstermiştir. Bunlar sayesinde kaynak kişiler, kurdukları münasebetlerin gerçekliğinden emin olmuşlardır. Mehmed Emin Tokadî kaynak kişilerin rüyalarında kimi zaman ilahi bir ses, kimi zaman bir 1şık huzmesi, kimi zaman ise vücutsal formuyla bulunmuş ve onlarla çeşitli şekillerde irtibat kurmuştur.

Bugüne dair olan memorat türü örnekleri sayesinde Mehmed Emin Tokadî'nin toplum hafizasında ne kadar canlı ve dinamik bir şekilde yer aldığ aralığına bakıldığında da gencinden yaşlısına farklı yaş dilimlerinde oldukları ve farklı işleri yaptıkları görülmektedir. Kaynak kişiler sözlü iletişim, belgeseller, kitaplar, internet gibi kaynaklar aracılığıyla zat hakkında bilgi sahibi olduklarını belirtmiştir. Bunlar Mehmed Emin Tokadî’ye yönelik güncel bilginin menşeine işaret etmektedir.

Memoratların üretilmesi ve aktarılması Mehmed Emin Tokadî’nin uhrevi kişiliğini; dünden bugüne, bugünden yarına taşıyacaktır. Mehmed Emin Tokadî yaşamının son bulmasından yüzyıllar sonra bile bu anlatılar sayesinde son derece canlı ve dinamik bir dinî ve kültürel aktör olarak karşımıza çıkmaktadır. Bu tarz çalışmaların sayısının arttırılması toplumsal belleğin neler içerdiğinin kavranması açısından oldukça değerlidir.

\section{Kaynakça}

Balaban, T. (2013). Amasya Efsane, Menkabe ve Memoratlarl (Derleme - Inceleme - Metin). Yayımlanmamış Doktora Tezi, Atatürk Üniversitesi Sosyal Bilimler Enstitüsü, Erzurum.

Çetinkaya, M. A. (2010). Pir Sultan Abdal'in Şiirlerinde Felsefi ve Tasavvufi Temalar. Yayımlanmamış Yüksek Lisans Tezi, Fırat Üniversitesi Sosyal Bilimler Enstitüsü, Elazığ.

Çobanoğlu, Ö. (2003). Türk Halk Kültüründe Memoratlar ve Halk İnançları. Ankara: Akçă̆ Yayınlar1.

Freud, S. (2011). Rüyaların Yorumu, I-II (Çev: İhsan Kırıml1). Ankara: Alter Yayınları.

Fromm, E. (1990). Rüyalar, Masallar, Mitoslar (Sembol Dilinin Çözümlenmesi) (Çev: Aydın ArıtanKaan H. Öktem). İstanbul: Arıtan Yayınevi.

Gonzalez, M. (2007). Rüyalar ve Anlamları. İstanbul: Medyatik Yayınları.

Honko, L. (2015). "Memorates and the Study of Folk Beliefs."Journal of Folklore Institute (Linda Dégh ve Andrew Vázsonyi. "Memorat ve Ön-Memorat" (Çev: Ahmet Barış Ekiz), Millı̂ Folklor, 27, (105), 131-146.

Ilıcak, G. ve Aydınalp G.” (2019). “Amasya Türkülerinde Şehir İmajına Yönelik Bir Değerlendirme” RumeliDE Dil ve Edebiyat Araştırmalart Dergisi, 15, 167-194. https://doi.org/10.29000/rumelide.580492 
İmamoğlu, A. (2004). Psiko-Sosyal Açıdan Rüya ve İstihare. Sakarya: Değişim Yayınları.

Kara, M. (2006). "Buhara-Bombay Bursa Hattında Dervişlerin Seyr ü Seferi." Dîvân İlmî Araştırmalar, 20, (1), 45-73.

Kaya, D. (2007). Ansiklopedik Türk Halk Edebiyatı Terimler Sözlügü. Ankara: Akçağ Yayınları.

Koç, A. (2012). "Üryan Hızır Ocağı Taliplerinden Zehra Kayacık ve Memoratlarının Etkisiyle Oluşan Nefesler Üzerine.” Türk Kültürü ve Hacı Bektaş Veli Araştırma Dergisi, 63, 265296.

Köksal, İ. (2008). “Rüyaların Fıkhi Boyutu.” Firat Üniversitesi Illahiyat Fakültesi Dergisi, 2, 35-53.

Merter, M. (2008). Dokuz Yüz Katlı İnsan (5. Baskl). İstanbul: Kaknüs Yayınları.

Nas, B. (2018). Aşkın Şehri Amasya'dan Geçenler. İstanbul: Akademik Kitaplar.

Ocak, A. Y. (1997). Kültür Tarihi Kaynağı Olarak Menakıbnameler (Metodolojik Bir Yaklaşım). Ankara: Türk Tarih Kurumu Yayınları.

Parladır, H. S. (2010). Heterodoksi Türk Halk İslamı ve Evliya Kültü. Yayımlanmamış Doktora Tezi, Ege Üniversitesi Sosyal Bilimler Enstitüsü, İzmir.

Pehlivan, G. (2009). “Dinî Şahsiyetler Hakkında Oluşan Anlatılar.” Milli Folklor, 83, (21), 88-96.

Peker, H. (2003). Din Psikolojisi. İstanbul: Çamlıca Yayınları.

Şimşek, H. İ. (2003). "Mehmed Emin Tokadî”, TDV İslâm Ansiklopedisi, Ankara: Türkiye Diyanet Vakfi, C: 28, 467-468.

Şimşek, H. İ. (2012). "Mehmed Emin Tokadî’nin Hayat1, Eserleri ve Tasavvufi Şahsiyeti”. Tokat Sетровуити (1-3 Kasim), C: 3, 389-402.

Tatçı M. ve Çeltik H. (1995). Türk Edebiyatında Tasavvufi Rüya Tabirnameleri. Ankara: Akçağ Yayınları.

Yüksel, H. A. (1996). Türk-İslam Tasavvuf Geleneğinde Rüya. Ankara: MEB Yayınları.

\section{Sözlï Kaynaklar}

Aşağıda kaynak kişiler hakkında bilgi verilirken şu sıraya bă̆lı kalınmıştır: a. Soyadı, Adı, b. Yaşı, c. Doğum yeri, ç. Mesleği, d. Derleme tarihi ve kimden derlendiği.

(K1) a. Arslan, Elif, b. 55, c. İstanbul, ç. Ev hanımı, d. 02.05.2019'da Mehmed Emin Tokadî Türbesi'nde Kerem Uyanık tarafından yapılan görüşme.

(K2) a. Çetin, Iş1k, b. 35, c. İstanbul, ç. Öğretmen, d. 20.05.2019'da Mehmed Emin Tokadî Türbesi'nde N. Gamze Ilıcak tarafından yapılan görüşme.

(K3) a. Dağ, Mevlüthan Nermin, b. 60, c. İstanbul, ç. Ev hanımı, d. 11.03.2019'da Mehmed Emin Tokadî Türbesi'nde Esra Şevlük ve Rümeysa Çetin tarafından yapılan görüşme.

(K4) a. Değirmenci, Zeycan, b. 29, c. İstanbul, ç. Ev hanımı, d. 02.05.2019'da Mehmed Emin Tokadî Türbesi'nde Aycan Değirmenci tarafından yapılan görüşme.

(K5) a. Durmaz, Cevriye, b. 46, c. İstanbul, ç. Ev hanımı, d. 10.04.2019'da Mehmed Emin Tokadî Türbesi'nde İpek Sunar ve Ayşenur Güngör tarafından yapılan görüşme.

(K6) a. Durmuş, Enes, b. 32, c. Ankara, ç. İşçi, d. 15.04.2019'da Mehmed Emin Tokadî Türbesi'nde Melike Küçüksolak tarafından yapılan görüşme. 
(K7) a. Ekici, Mert, b. 25, c. İstanbul, ç. Öğrenci, d. 01.05.2019'da Mehmed Emin Tokadî Türbesi'nde Kerem Uyanık tarafindan yapılan görüşme.

(K8) a. Fatma, Zeynep, b. 46, c. İstanbul, ç. Ev hanımı, d. 30.04.2019'da Mehmed Emin Tokadî Türbesi'nde Aycan Değirmenci tarafindan yapılan görüşme.

(K9) a. Gencer, Leyla, b. 46, c. İstanbul, ç. Ev hanımı, d. 01.05.2019'da Mehmed Emin Tokadî Türbesi'nde Aycan Değirmenci tarafından yapılan görüşme.

(K10) a. Koçer, Barış, b. 25, c. Ağrı, ç. Öğrenci, d. 23.04.2019'da Mehmed Emin Tokadî Türbesi’nde Esra Şevlük ve Rümeysa Çetin tarafindan yapılan görüşme.

(K11) a. Öztürk, Serpil, b. 52, c. Giresun, ç. Ev hanımı, d. 23.04.2019'da Mehmed Emin Tokadî Türbesi'nde Esra Şevlük ve Rümeysa Çetin tarafindan yapılan görüşme.

(K12) a. Şimşek, Zübeyde, b. 21, c. İstanbul, ç. Öğrenci, d. 15.04.2019'da Mehmed Emin Tokadî Türbesi'nde Melike Küçüksolak tarafindan yapılan görüşme.

(K13) a. Tandır, Necla, b. 55, c. İstanbul, ç. Ev hanımı, d. 25.05.2019'da Mehmed Emin Tokadî Türbesi'nde N. Gamze Ilıcak tarafindan yapılan görüşme.

(K14) a. Tütüncüler, Cafer, b. 54, c. Ankara, ç. Aşçı, d. 19.04.2019'da Mehmed Emin Tokadî Türbesi’nde İpek Sunar ve Ayşenur Güngör tarafından yapılan görüşme.

(K15) a. Yükse, Şule, b. 40, c. İstanbul, ç. Öğretmen, d. 07.06.2019'da Mehmed Emin Tokadî Türbesi'nde N. Gamze Ilıcak tarafindan yapılan görüşme. 